\title{
Large losses in glacier area and water availability by the end of twenty-first century under high emission scenario, Satluj basin, Himalaya
}

\author{
Veena Prasad $^{1}$, Anil V. Kulkarni ${ }^{1} *$, S. Pradeep ${ }^{1}$, S. Pratibha ${ }^{1}$, Sayli A. Tawde ${ }^{2}$, \\ Tejal Shirsat ${ }^{1}$, A. R. Arya ${ }^{1}$, Andrew Orr $^{3}$ and Daniel Bannister ${ }^{3}$ \\ ${ }^{1}$ Divecha Centre for Climate Change, \\ ${ }^{2}$ Centre for Atmospheric and Oceanic Sciences, Indian Institute of Science, Bengaluru 560012 , India \\ ${ }^{3}$ British Antarctic Survey, Cambridge, CB3 0ET, UK
}

Glaciers in the Satluj river basin are likely to lose $53 \%$ and $81 \%$ of area by the end of the century, if climate change followed RCP 8.5 scenario of CNRMCM5 and GFDL-CM3 models respectively. The large variability in area loss can be due to difference in temperature and precipitation projections. Presently, Satluj basin has approximately 2000 glaciers, $1426 \mathrm{sq}$. km glacier area and $62.3 \mathrm{Gt}$ glacier stored water. The current mean specific mass balance is -0.40 m.w.e. $a^{-1}$. This will change to -0.42 and -1.1 m.w.e. $\mathrm{a}^{-1}$ by 2090 , if climate data of CNRM-CM5 and GFDL-CM3 are used respectively. We have used an extreme scenario of GFDL-CM3 model to assess the changes in the contribution of glacier melt to the Bhakra reservoir. Mass balance model suggests that glaciers are contributing $2 \mathrm{~km}^{3} \mathrm{a}^{-1}$ out of $14 \mathrm{~km}^{3}$ of water. This will increase to $2.2 \mathrm{~km}^{3} \mathrm{a}^{-1}$ by 2050 , and then reduce to $1.5 \mathrm{~km}^{3} \mathrm{a}^{-1}$ by the end of the century. In addition, loss in glacier area by the end of century, will also increase the vulnerability of mountain communities, suggesting need for better adaptation and water management practices.

Keywords: Climate change, glacier, glacier melt runoff, Himalaya, mass balance, Satluj basin, water availability.

THE Satluj river is a major source for irrigation and hydroelectric power projects in Northern India ${ }^{1,2}$. It is the largest tributary of river Indus and flows from the Tibetan plateau through Himachal Pradesh and Punjab, India. At Bhakra, Himachal Pradesh, a major dam is constructed to utilize water for hydroelectricity generation and irrigation. The reservoir also receives water from the Beas river through the Beas-Satluj link ${ }^{3}$. The Bhakra reservoir (Govind Sagar) has a capacity of 9340 million cubic metres and receives $65-80 \%$ of its inflow from Satluj river and the remaining $20-35 \%$ from the Beas river $^{3-5}$. The

*For correspondence. (e-mail: anilkulkarni@iisc.ac.in)
Satluj river supports generation of $4566 \mathrm{MW}$ of hydropower, with potential for future expansion ${ }^{6}$.

The headwaters of the Satluj river consist of a glaciated area of $1426 \mathrm{sq} . \mathrm{km}$ (Figure 1). Melt water from these glaciers and seasonal snow contribute significantly to the river runoff ${ }^{2,7}$. More than $50 \%$ of the annual flow of Satluj river is contributed by snow and ice melt ${ }^{8,9}$. However, water reserves held by glaciers are likely to be altered considerably in the future due to climate change, as glaciers are highly sensitive to variations in temperature and precipitation ${ }^{10-13}$. Observations show that nearsurface air temperature in North Western Himalaya has increased by $0.65^{\circ} \mathrm{C}$ during $1991-2015$, as compared to the mean global temperature rise of $0.47^{\circ} \mathrm{C}$ (refs 14-16). This is influencing the mass and area of glaciers in the Himalaya $^{13,17-23}$. In addition, these changes will also affect the snow and glacier melt runoff and water availability ${ }^{2,24-26}$. Therefore, an in-depth understanding of these issues is imperative to develop adaptation and management strategies for the future. In this paper, we assess the response of Satluj basin glaciers to the changes in precipitation and temperature from 1984 to 2090 (Figure 1). Glacier stored ice and mass budgets are calculated to understand the present state of glaciers. Further, changes in the areal extent of glaciers for the 21 st century are estimated for the high emission representative concentration pathway (RCP) 8.5 scenario, based on the projections from two global climate models (GCM). Lastly, future contribution of glacier melt to the Bhakra reservoir is estimated.

\section{Methodology}

The methodology consists of estimating the following major components: (1) Volume of glacier stored water using velocity-slope and volume-area scaling ( $V-A$ scaling) methods ${ }^{27,28}$, (2) Annual mass balance using improved accumulation area ratio (IAAR) and geodetic 


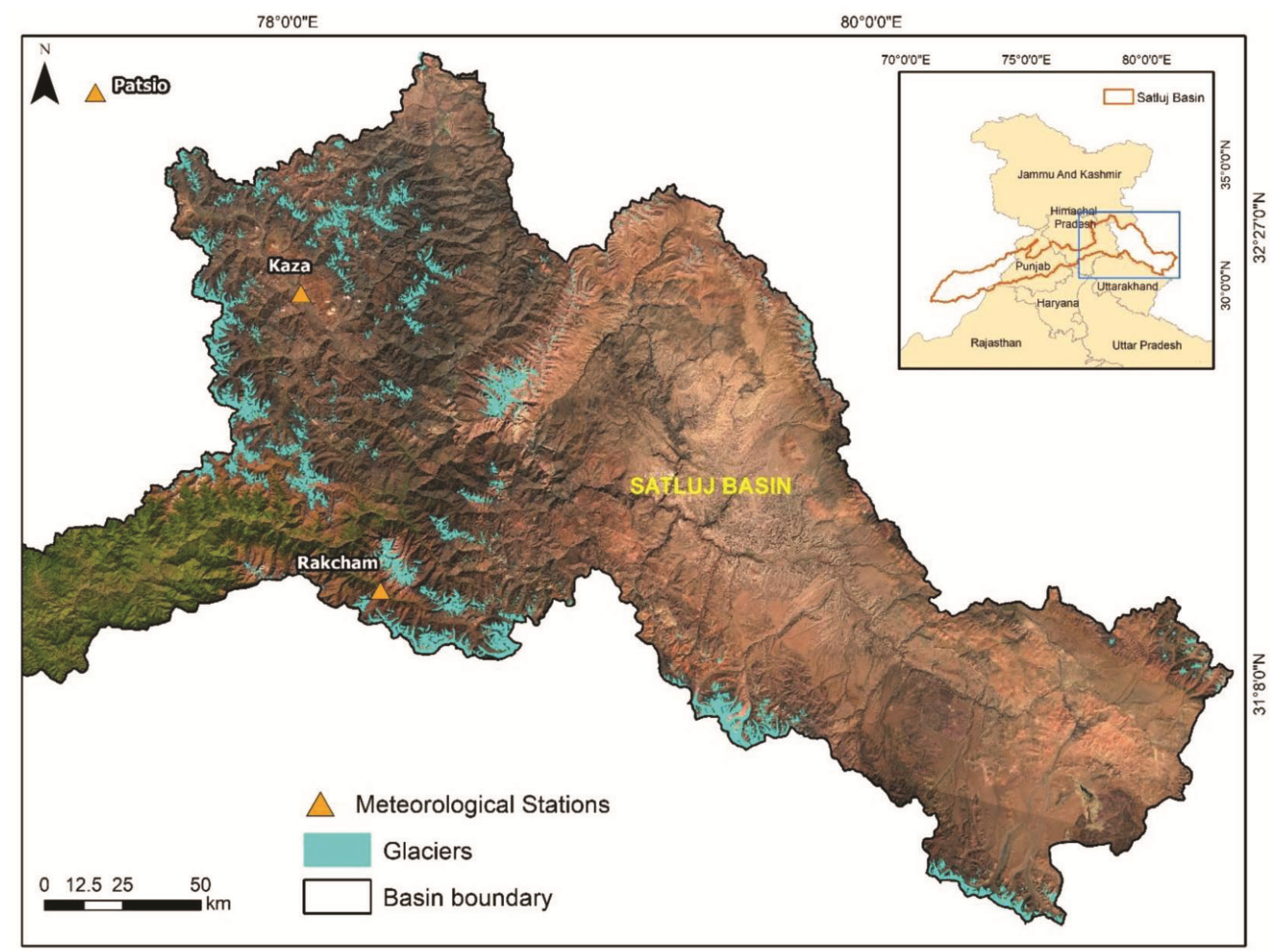

Figure 1. Map of the Satluj basin showing location of the meteorological stations. The basin consists of 2026 glaciers covering an area of $1426 \mathrm{sq}, \mathrm{km}$. The glacier elevation ranges from 3944 to $7349 \mathrm{~m}$ amsl.

methods ${ }^{13,29}$, (3) Future glacier mass balance, area, volume $^{30}$ and water availability; and (4) uncertainty in the mass balance and volume estimates (Figure 2).

\section{Estimation of glacier stored ice}

\section{Velocity-slope method}

Glacier depth is estimated using the following equa$\operatorname{tion}^{27,31}$

$$
H=\sqrt[4]{\frac{1.5 U_{S}}{A f^{3}(\rho g \sin \alpha)^{3}}}
$$

where $H$ is the ice thickness (m); $\rho$ the ice density $\left(900 \mathrm{~kg} \mathrm{~m}^{-3}\right) ; g$ the acceleration due to gravity $\left(9.8 \mathrm{~m} \mathrm{~s}^{-2}\right)$; $f$ the shape factor $(0.8) ; A$ the creep parameter $\left(3.24 \times 10^{-24}\right.$ $\left.\mathrm{Pa}^{-3} \mathrm{~s}^{-1}\right), U_{\mathrm{s}}$ the surface velocity $\left(\mathrm{m} \mathrm{s}^{-1}\right)$ and $\alpha$ is the slope angle.

The key parameters, surface velocity and slope are estimated using remote sensing data. Landsat images dur- ing the ablation season of 2000, 2001, 2002, 2013, 2014, 2015 and 2016 are used to estimate the surface velocity using sub-pixel level correlation ${ }^{27,32}$. Slope is estimated at an interval of $100 \mathrm{~m}$ using advanced spaceborne thermal emission and reflection radiometer (ASTER DEM) ${ }^{27}$. Glacier boundaries and area are derived from Randolph glacier inventory version 5 (RGI). Velocity-slope method is applied to 238 glaciers and for the remaining 1788 glaciers, surface velocity could not be estimated due to small glacier size, unseasonal snow, cloud and debris cover.

\section{$V-A$ scaling equation}

For 1788 glaciers, volume is estimated using $V-A$ scaling method (based on volume estimates developed from velocity-slope method). The volume of the glacier $(V)$ is related to its area $(A)$ according to the power law

$$
V=C_{A} \times A^{\gamma}
$$

where $\gamma$ is the scaling exponent and $C_{A}$ is the constant of proportionality $\left(\mathrm{km}^{3-2 \gamma}\right)$. As mentioned earlier, we estimated 


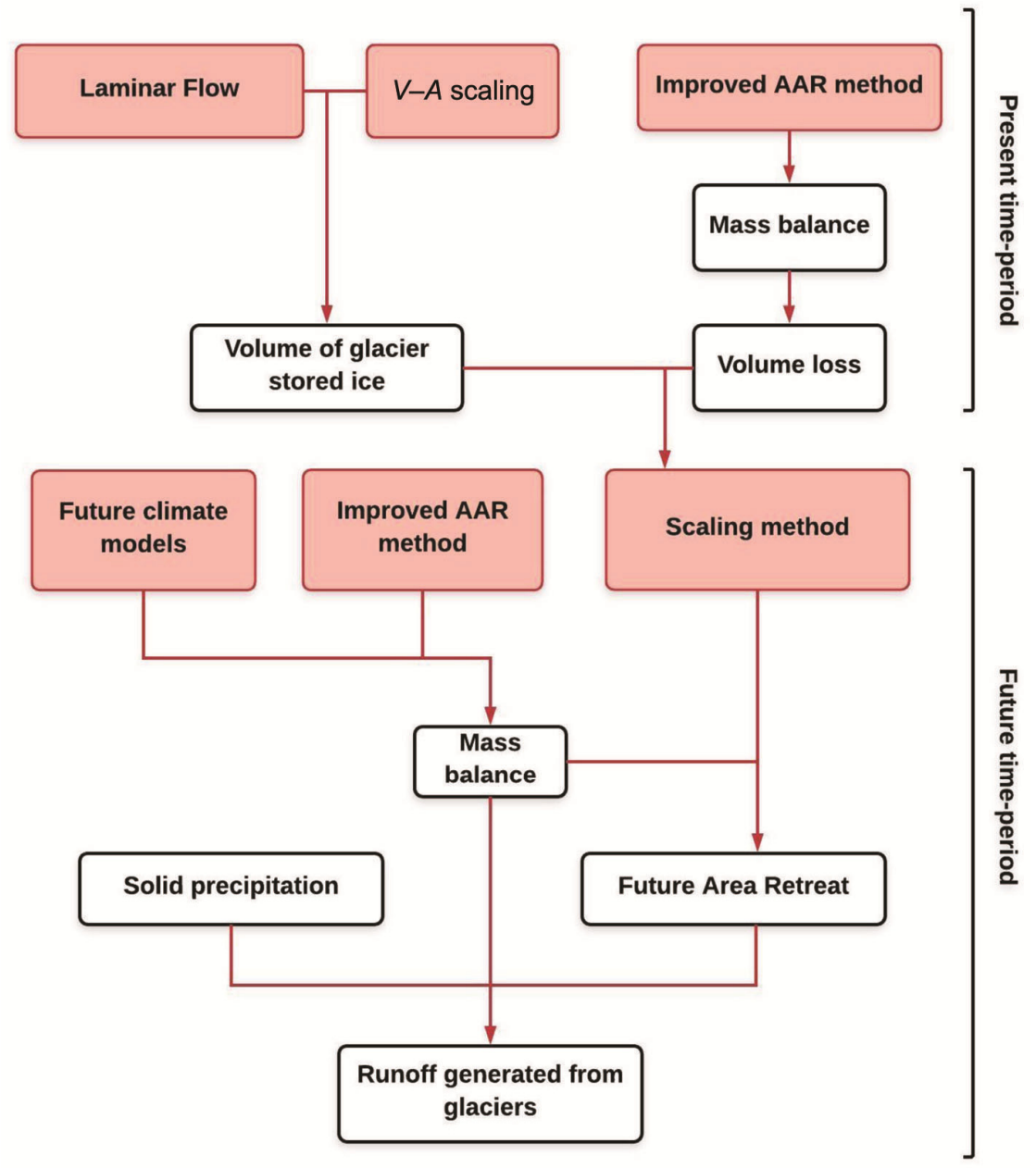

Figure 2. Flow diagram for estimation of glacier volume, mass balance, future changes in the glacier area and glacier melt runoff.

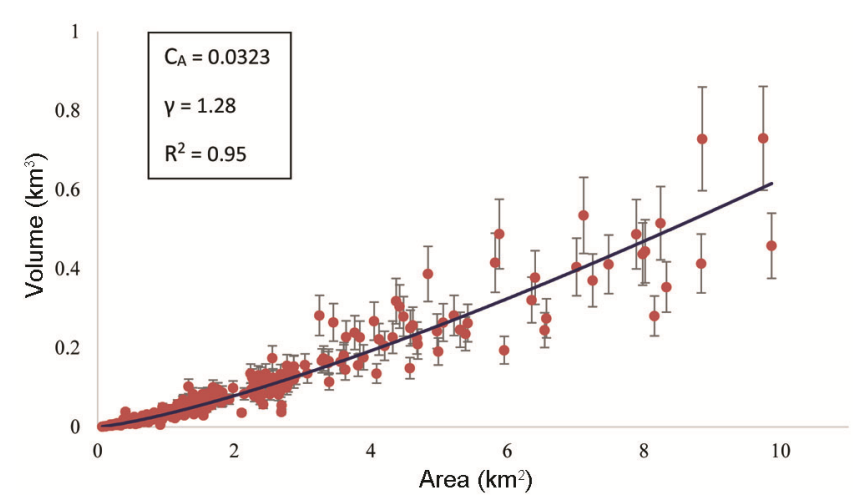

Figure 3. Volume-area relationship in Satluj and Beas basins. The relationship is developed using 298 glaciers, whose areal extent is less than $10 \mathrm{sq} . \mathrm{km}$.

the volume for 238 glaciers using velocity-slope method. Out of these, 229 glaciers had an area of less than 10 sq. km. These 229 glaciers along with 69 glaciers from Beas basin are used to derive the power law constants (Figure 3). The $V-A$ scaling equation is then used to estimate volume for the remaining 1788 glaciers.

\section{Glacier mass balance estimation for the present condition}

\section{Estimation of annual glacier mass balance}

In the IAAR method ${ }^{29}$, AAR is modelled, which is the ratio of accumulation area to the total area of the glacier. This method uses climate data (temperature and precipitation) and temperature index (TI) to estimate the position of equilibrium line altitude (ELA). The temperature and precipitation data of Kaza and Rakcham meteorological stations (see Figure 1 for their locations) were used to estimate snow melt and accumulation. The glacier melt at different elevation zones was calculated using lapse rates and the TI model. Transient snow lines and precipitation gradients $(\mathrm{PG})^{29}$ were derived from Landsat images between 1992 and 2011. The spatial distribution of snow accumulation was calculated using station snowfall data (October to April) and PG (Table 1). Using ELA and hypsometry, AAR was calculated for individual glaciers. Further, the annual specific mass 
balance (MB) was estimated using the following regression equation

$$
\mathrm{MB}(\mathrm{cm} . \mathrm{w} . \mathrm{e})=a^{*} \mathrm{AAR}-b,
$$

where $a$ and $b$ are regression coefficients. Tawde et $a l .{ }^{13}$ derived the values of $a$ and $b$ for the adjacent Chandra basin using field measurements between 1987 and 2012 and then validated in the Baspa basin ${ }^{29}$.

\section{Validation of IAAR method with the geodetic method}

Mass balance estimates by IAAR method were validated using the geodetic method in Baspa basin for 25 glaciers covering an area of $66 \pm 3.3 \mathrm{sq} . \mathrm{km}$. Geodetic method estimates the glacier mass balance using elevation difference between two time periods. DEM for 2014 was derived from Cartosat- 1 stereo pair data using the rational polynomial coefficient (RPC) method $^{33}$. In addition, 250 well distributed tie points and 23 differential global positioning system (GPS) points were used as ground control points to improve the accuracy of DEM. These differential GPS points were collected during a field survey in 2016 and 2017. Another set of 21 differential GPS points were used to check the accuracy of DEMs.

Removing the shift between two DEMs is a prerequisite before determining the glacier elevation change. The difference between the elevation (dh) of Shuttle Radar Topography Mission (SRTM) and Cartosat DEM on stable area was considered to determine the vertical and horizontal shift using the analytical solution provided by Nuth and $\mathrm{Kaab}^{34}$. A total shift of $11 \mathrm{~m}$ in the north-south and $35 \mathrm{~m}$ in the east-west direction were determined and the two DEMs were co-registered. Further, spatial trend correction was applied to Cartosat DEM by deriving a surface trend of third order polynomial using stable area dh points ${ }^{35}$. As radar signal penetrates through glacier surfaces like snow and ice, a penetration correction of $2.1 \pm 0.4 \mathrm{~m}$ for SRTM data was applied ${ }^{36}$. Penetration correction was not applied on supra-glacial debris cover, where the depth of seasonal snow was less than the penetration depth. Supra-glacial debris cover extent for the year 2000 for individual glaciers was taken from Pratibha and Kulkarni ${ }^{37}$. The seasonal snow depth at different elevation zones of the glacier was calculated using daily snowfall data from Rakcham station and the modelled PG

Table 1. Precipitation gradient $(\% / \mathrm{m})$ with standard deviation estimated for the study areas

\begin{tabular}{lccc}
\hline Basin & & $\begin{array}{c}\text { Station data used } \\
(\mathrm{m} \text { amsl) }\end{array}$ & $\begin{array}{c}\text { Precipitation gradient } \\
(\% / \mathrm{m})\end{array}$ \\
\hline \multirow{2}{*}{ Satluj } & Spiti & Kaza (3600) & $0.11 \pm 0.06$ \\
& Baspa & Rakcham (3050) & $0.03 \pm 0.02$ \\
& Others & Kaza (3600) & $0.18 \pm 0.09$ \\
\hline
\end{tabular}

for Baspa. Further, this data was used as a seasonal correction for seasonal snow accumulation during different acquisition dates of the two DEMs. Before computing the elevation difference, pixels with slope greater than $35^{\circ}$ or $\mathrm{dh}>3 \sigma$ (standard deviation) were removed as outliers. The area weighted dh was computed for each $50 \mathrm{~m}$ elevation zone and converted to mass change by assuming an average density of $850 \pm 50 \mathrm{~kg} \mathrm{~m}^{-3}$ (refs 36, 38). Uncertainties in mass budget estimation, density assumption, radar penetration values and DEM differencing were assessed following the procedure by Pieczonka and Bolch $^{39}$.

\section{Mass balance and area retreat estimation for future years}

Fourteen models of the Coupled Model Intercomparison Project (CMIP5) ${ }^{40}$ were identified as the suitable models for representing the precipitation climatology of western Himalaya region by Palazzi et al. ${ }^{41}$. In the present analysis, out of these 14 models, outputs of two GCMs projecting possible climate extremes were selected. Of these, the GFDL-CM3 model showed the highest warming over the Satluj by the end of the century, while the CNRM-CM5 model showed the lowest warming, and thus the two models provided a good spread of possible future temperatures. In addition, the CNRM-CM5 model showed one of the highest increases in precipitation over Satluj by the end of the century and GFDL-CM3 showed a relatively dry climate till the middle of the century, followed by a wetter climate towards the end of the century.

The climate model output was used to estimate the change factor $(\mathrm{CF})^{42}$ and applied on field measurements to estimate future temperature and snowfall. Change factor is the difference between the present and future temperature and precipitation values. A multiplicative and an additive change factor were used for precipitation and temperature estimation respectively. Future glacier area changes were estimated using the $V-A$ scaling method, as given below $^{30}$

$$
\mathrm{d} V_{n}=\left(A_{n} \times M B_{n} \times t\right),
$$

where $A_{n}$ is the surface area for $n$th time step, $M B_{n}$ the surface mass balance; $t$ is the number of years. The volume of the next time step $(n+1)$ is calculated as $V_{n+1}=V_{n}+\mathrm{d} V_{n}$, where $V_{n}$ is the volume of glacier at the $n$th time step.

The surface area changes for $n+1$ th time step is estimated using the relationship

$$
\mathrm{d} A_{(n+1)}=\frac{1}{\tau A_{n}}\left(\left(\frac{V_{(n+1)}}{C_{A}}\right)^{1 / \gamma}-A_{n}\right),
$$


The values of $\gamma$ and $C_{A}$ are adopted from the $V-A$ equation developed for the current scenario (eq. (2)). The response time of the area $\tau_{A n}$ (in year), is estimated as

$$
\tau A_{n}=\tau L_{n}\left(\frac{A_{n}}{L_{n}^{2}}\right)
$$

where $L_{n}(\mathrm{~km})$ is the length of the glacier and $\tau_{L n}$ is the length response time in year. The length of the glaciers is calculated from the following volume-length $(V-L)$ scaling (equation):

$$
\text { Volume }=C_{L} \times(\text { length })^{q},
$$

where $q$ is the scaling exponent and $C_{L}$ is the constant of proportionality $\left(\mathrm{km}^{3-q}\right)$.

The length response time $\tau_{L_{n}}$ (refs 30,43 ), is calculated as

$$
\tau_{L_{n}}=\frac{V_{n}}{P^{\text {solid }} n}
$$

where $P^{\text {solid }} n\left(\mathrm{~km}^{3}\right)$ is the annual snowfall received on the glacier.

We assumed that any changes that occurred in the area would be from the glacier terminus. Hypsometry can be updated for the future period by removing area from the glacier snout. Change in the glacier length for each time step is given by

$$
\mathrm{d} L=\frac{1}{\tau_{L_{n}}}\left(\left(\frac{V_{n+1}}{C_{L}}\right)^{1 / q}-L_{n}\right)
$$

$C_{L}$ is the proportionality constant $\left(\mathrm{km}^{3-q}\right)$ calculated from $V-L$ power law.

Estimation of AAR for future period with current area leads to an overestimation of area and volume loss. Therefore, multiple iterations are done till the difference in volume loss between iterations is negligible (this was typically achieved after the second iteration).

\section{Glacier water availability}

To estimate the contribution of glacier melt to stream runoff, we considered the results of mass balance model. The amount of glacier runoff is estimated as the sum of melt contributions from negative mass balance and solid precipitation on the glacier. These calculations are done only for the GFDL-CM3 output. While calculating contribution from solid precipitation, the change in glacier area with respect to time is not considered as the initial glacier area will continue to receive precipitation even after glacier recedes/disappears ${ }^{44}$.

\section{Uncertainty estimates}

The uncertainty in depth estimates is quantified by using the equation

$$
\frac{\mathrm{d} H}{H}=\sqrt{\left(\frac{1}{4} \frac{\mathrm{d} U_{s}}{U_{S}}\right)^{2}+\left(\frac{3}{4} \frac{\mathrm{d} f}{\mathrm{f}}\right)^{2}+\left(\frac{3}{4} \frac{\mathrm{d} \rho}{\rho}\right)^{2}+\left(\frac{3}{4} \frac{\mathrm{d} \sin \alpha}{\sin \alpha}\right)^{2}} .
$$

where $H$ is the ice thickness (m); $\rho$ the ice density $\left(900 \mathrm{~kg} \mathrm{~m}^{-3}\right) ; f$ the shape factor $(0.8) ; U_{s}$ the surface velocity $\left(\mathrm{m} \mathrm{s}^{-1}\right)$ and $\alpha$ is the slope angle.

Uncertainty in $U_{\mathrm{s}}$ can arise from orthorectification and co-registration errors in the satellite images, and the accuracy of co-registration of Optically Sensed Images and Correlation (COSI-Corr) ${ }^{45}$. Uncertainty in $f$ is considered as $\pm 12.5 \%$ and the uncertainty in $\rho$ is taken as $\pm 10 \%$. Uncertainty in $\sin \alpha$ arises due to vertical inaccuracies in DEM and is taken as $\pm 8.7 \%$ (ref. 45 ). The overall model uncertainty in volume estimation is $\pm 18 \%$, which is computed from the scaling equation,

$$
\frac{\mathrm{d} V_{S}}{V_{S}}=n \frac{\mathrm{d} A}{A} .
$$

Uncertainty in mass balance was estimated using the standard deviation in temperature and precipitation. Current area uncertainty values are taken as 5\% from the RGI v5 (ref. 46). Future area uncertainty is estimated based on standard propagation of errors for independent variables $^{47}$.

\section{Results}

\section{Present glacier ice volume}

Our estimate of the total glacier stored water for 2026 glaciers in Satluj basin was $69 \pm 12 \mathrm{~km}^{3}$. The spatial distribution of glacier stored water of individual glaciers is shown in Figure 4. About $56 \%$ of the total volume $\left(37.6 \mathrm{~km}^{3}\right)$ is stored in large glaciers (area $>5 \mathrm{sq} . \mathrm{km}$ ) covering an area of $517 \pm 26 \mathrm{sq} . \mathrm{km}$. The largest glacier of the study area is in the Tibetan region, which occupies an area of $66.8 \mathrm{sq} . \mathrm{km}$ and contains $6.5 \mathrm{Gt}$ of ice. Most of the glaciers $(\sim 95 \%)$ contain less than $0.1 \mathrm{Gt}$ of ice.

\section{Present glacier mass balance}

The mean annual glacier mass balance of Satluj basin from 1984 to 2013 is $-0.40 \pm 0.47$ m.w.e. $\mathrm{a}^{-1}$. The mass balance estimates show a negative trend with a decadal decrease of -0.14 m.w.e. $\mathrm{a}^{-1}$. The inter-annual glacier mass balance of the basin is shown in Figure 5 and the 
spatial distribution of mean mass balance is shown in Figure 6. The basin lost 21\% (16.4 Gt) of glacier volume during 1984-2013.

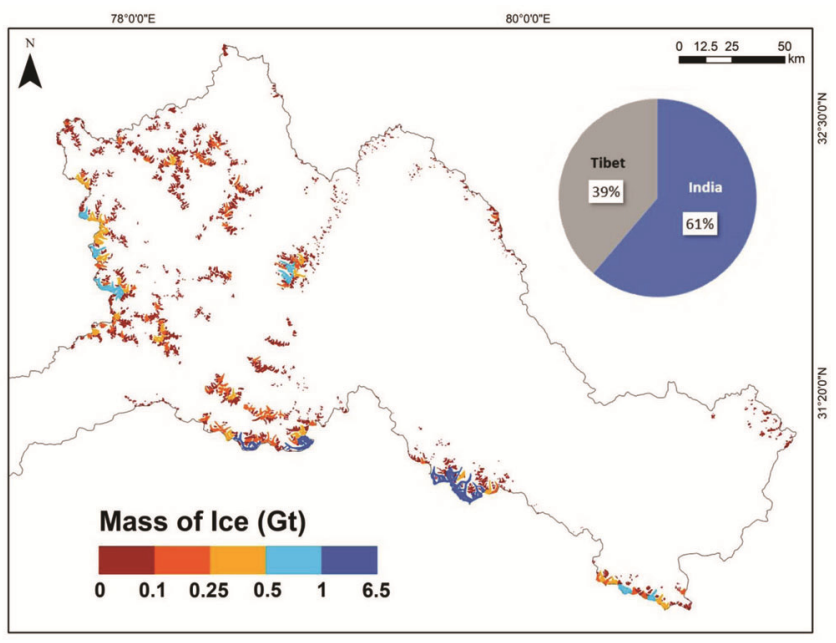

Figure 4. Spatial distribution of glacier mass. The total amount of glacier mass in Satluj basin is $62 \pm 11 \mathrm{Gt}$.

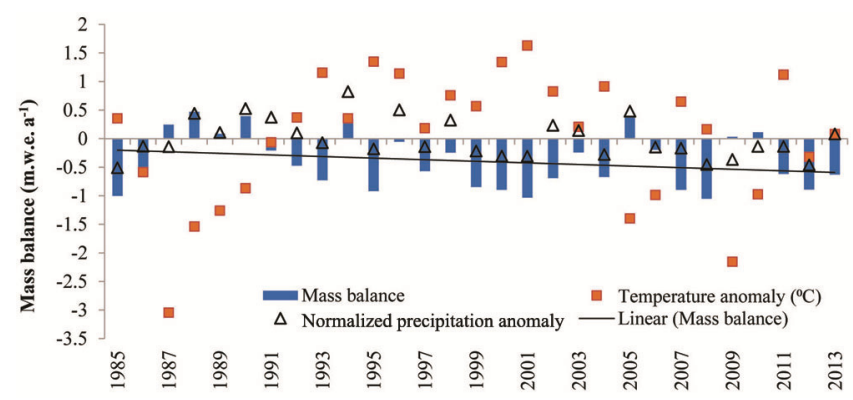

Figure 5. Inter-annual variation of glacier mass balance. The area weighted annual mass balance ranges between $-1.05 \pm+0.47$ and $0.47 \pm 0.47$ m.w.e. $\mathrm{a}^{-1}$ during 1984-2013.

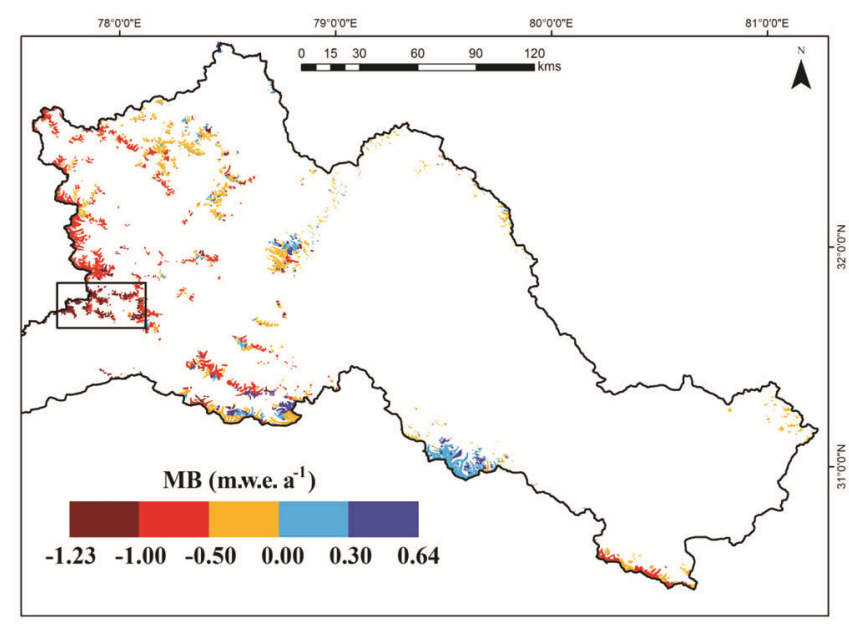

Figure 6. Spatial distribution of mean glacier mass balance between 1984 and 2013. The region with highest negative mass balance is shown within the rectangular box.
Model estimates of the mass loss were validated by geodetic method for 25 glaciers in Baspa basin from 2000 to 2014. Mass balance estimates based on the geodetic and IAAR methods were $-0.27 \pm 0.43$ m.w.e. $\mathrm{a}^{-1}$ and $-0.24 \pm 0.47$ m.w.e. $\mathrm{a}^{-1}$ respectively. The slight difference in the estimates was partly due to the discrepancy in the time period as the data was not available for 2014 in the IAAR method. The mass balance estimates for individual glaciers by geodetic method ranged between -0.81 and 0.34 m.w.e. $\mathrm{a}^{-1}$, with an uncertainty of \pm 0.43 m.w.e. $\mathrm{a}^{-1}$. Mean mass balance estimated by the IAAR method is therefore broadly in agreement with the geodetic method. However, mass loss estimated by the IAAR method was higher than that by geodetic method for the heavily debris covered glaciers. This is because the influence of debris cover on mass balance accounted in IAAR method is confined to the glacier on which the AAR-mass balance regression is developed ${ }^{29}$.

\section{Future changes}

According to the CNRM-CM5 projections, by 2050 (averaged over 2045-2055), the Satluj basin will experience an increase in summer temperature by $1.48^{\circ} \mathrm{C}$ and $8 \%$ decrease in winter snowfall compared to 2010 (averaged over 2005-2015). By 2090 (averaged over 20852095), the CNRM-CM5 model predicts an increase of $3.5^{\circ} \mathrm{C}$ in summer temperature and $24 \%$ increase in winter precipitation. Based on these values, the mean ELA of the basin will ascend by $44 \mathrm{~m}$ and $152 \mathrm{~m}$ by 2050 and 2090 respectively (Table 2 ).

The projections from GFDL-CM3 model compared to the present day values (2005-2015) show a rise of $3.7^{\circ} \mathrm{C}$ and $7.94^{\circ} \mathrm{C}$ in the summer temperature by 2050 and 2090 respectively. The model also shows that the winter snowfall for 2050 and 2090 will reduce by $14 \%$ and $5 \%$ respectively. Based on these values, ELA would ascend by $269 \mathrm{~m}$ and $811 \mathrm{~m}$ by 2050 and 2090 respectively. The faster ascent of ELA in GFDL-CM3 projection compared to CNRM-CM5 projection is due to the former simulating a larger temperature increase and precipitation decrease.

The area weighted annual mass balance estimated for Satluj basin changes from -0.22 m.w.e. $\mathrm{a}^{-1}$ to

Table 2. Equilibrium line altitude estimates for the future periods using GFDL-CM3 and CNRM-CM5 projections

\begin{tabular}{|c|c|c|c|}
\hline \multirow[b]{2}{*}{ Basin } & \multirow[b]{2}{*}{ Period } & \multicolumn{2}{|c|}{$\mathrm{ELA}_{\text {avg }}(\mathrm{m}$ amsl) } \\
\hline & & CNRM-CM5 & GFDL-CM3 \\
\hline \multirow[t]{5}{*}{ Satluj } & 2010 & \multicolumn{2}{|c|}{5648} \\
\hline & 2030 & 5500 & 5700 \\
\hline & 2050 & 5692 & 5917 \\
\hline & 2070 & 5659 & 6300 \\
\hline & 2090 & 5800 & 6459 \\
\hline
\end{tabular}


-0.42 m.w.e. $\mathrm{a}^{-1}$ (CNRM-CM5 output) and from -0.60 m.w.e. $\mathrm{a}^{-1}$ to -1.10 m.w.e. $\mathrm{a}^{-1} \quad$ (GFDL-CM3 output) between 2030 and 2090. This results in a cumulative mass loss of $52 \%$ (41 Gt) according to CNRM-CM5 output and $78 \%(62 \mathrm{Gt})$ according to GFDL-CM3 output between 1985 and 2090 (Figure 7). We estimated a subsequent change in area using $V-A$ scaling, which suggested that the current area would reduce by $15 \%$ (218 sq. km) by 2050 and $53 \%$ (750 sq. km) by 2090 based on the CNRM-CM5 output. Whereas GFDL-CM3 output showed that there would be 33\% (475 sq. km) and $81 \%$ (1157 sq. km) glacier area reduction by 2050 and 2090 respectively. However, this loss in the area is not uniform. According to GFDL-CM3 output, around 55\% of the glaciers in Satluj basin are likely to disappear by 2050 , and by 2090 only $3 \%$ of the total glaciers will remain (Figure 8). Also, the highest percentage of recession in area is projected for smaller glaciers (area $<1 \mathrm{sq} . \mathrm{km}$ ). This is because of the shorter response time of small glaciers, making them more vulnerable to climate change. Glaciers with area less than $1 \mathrm{sq} . \mathrm{km}$ will experience approximately $62 \%$ of area loss by 2050 , while bigger glaciers (area $>10$ sq. $\mathrm{km}$ ) show a slower response to climate change with only $1 \%$ loss in their area. An example of the spatial distribution of area loss for a large glacier in Spiti basin (sub-basin of Satluj) is shown in Figure 9. The present area of the glacier $(13.80 \mathrm{sq} . \mathrm{km})$ is projected to reduce by $0.62 \mathrm{sq}$. $\mathrm{km}$ by 2050 and $5 \mathrm{sq} . \mathrm{km}$ by 2090 under GFDL-CM3 model scenario.

\section{Estimation of glacier contribution to Bhakra reservoir}

Persistent mass and area loss throughout the 21 st century will affect the downstream water availability. At present, the total runoff from Satluj basin to Bhakra dam is $\sim 14 \mathrm{~km}^{3} \mathrm{a}^{-1}$. According to our model results, in 2010, the Bhakra reservoir received $2 \mathrm{~km}^{3}$ of water from the

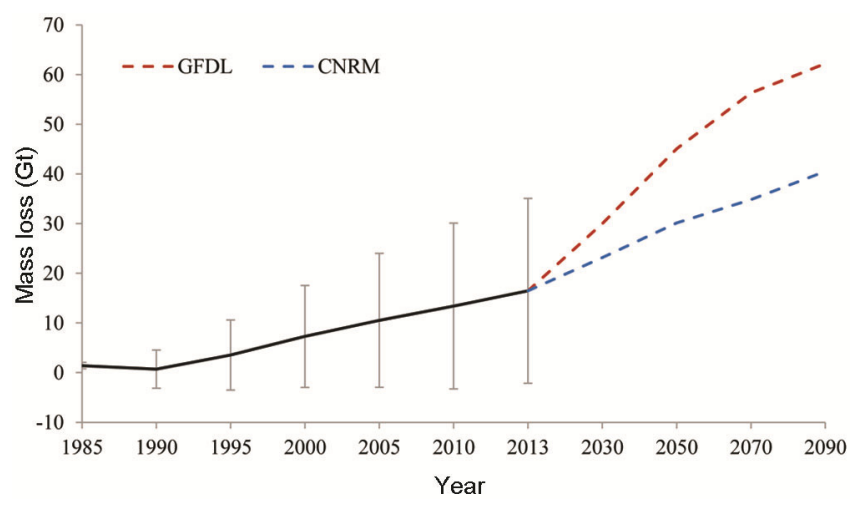

Figure 7. Solid line represents cumulative mass loss in Satluj basin for the current decades and dashed line is the projected mass loss up to the end of the century. This is for RCP 8.5 scenario using GFDL-CM3 and CNRM-CM5 models. Vertical error bars signify the uncertainty in mass estimation. glaciated terrain which accounts for $\sim 14 \%$ of the total runoff. The runoff will increase in future due to increased mass loss. Our results show that runoff will reach a maximum value (peak water) of $2.2 \mathrm{~km}^{3} \mathrm{a}^{-1}$ by 2050 , and then reduce to $1.49 \mathrm{~km}^{3} \mathrm{a}^{-1}$ by the end of the century due to glacier retreat (Figure 10).

\section{Conclusions and discussion}

The present study estimates the influence of climate change on glaciers in Satluj basin for the 21 st century using IAAR method, $V-A$ scaling method and projections from CNRM-CM5 and GFDL-CM3 models for RCP 8.5 scenario. Field meteorological data from 1984 to 2013 are used to estimate the past changes in glacier mass. Our model-derived mass balance estimates agree with those from other mass balance techniques at glacier/regional scale. IAAR and field mass balance estimates of Shaune Garang $\left(31.287^{\circ} \mathrm{N}, 78.397^{\circ} \mathrm{E}\right)$ and Naradu $\left(31.292^{\circ} \mathrm{N}\right.$, $78.339^{\circ} \mathrm{E}$ ), the benchmark glaciers in Baspa basin, are comparable. The modelled and field mass balance for Shaune Garang for $1985-1991$ is -0.59 m.w.e. $\mathrm{a}^{-1}$ and -0.44 m.w.e. $\mathrm{a}^{-1}$ respectively; and for Naradu glacier it is -0.40 m.w.e. $\mathrm{a}^{-1}$ for $2001-2003$. The mass balance estimates for Baspa basin by geodetic method match well with the IAAR method. Our model-derived mass balance estimates are also in agreement with the mass balance of neighbouring region estimated by other studies ${ }^{48}$. Future estimates of glacier area trends observed in retreat were compared with the published studies on Western Himalaya. Chaturvedi et al. ${ }^{12}$ projected an area loss of $17.9 \%$ and $54.8 \%$ for the Western Himalaya for 2050 and 2080 respectively, which is within the range of our estimates. Zhao et al. ${ }^{49}$ anticipated an area loss of $20-31 \%$ for the Western Himalaya based on A1B scenario (for a temperature rise of $\sim 3^{\circ} \mathrm{C}$ ) in 2050 . Our study estimates an area loss of $15-33 \%$ by 2050 in Satluj. Area loss projected in the present analysis is also in agreement with the estimates for the adjacent Upper Indus basin, i.e. $23-28 \%$ by 2050 (ref. 50). Our estimates for future glacier area have an uncertainty of $32 \%$.

Our investigation shows that the mean glacier mass loss in Satluj basin is $-0.40 \pm 0.47$ m.w.e. $\mathrm{a}^{-1}$ (or $0.57 \pm$ $0.64 \mathrm{Gt} /$ year) from 1984 to 2013. The current mass balance suggests that the loss rate has increased after 1990. In the coming decades, the basin will experience further increase in temperature and precipitation. However, the change in precipitation is not enough to offset the effect of increased melt due to warmer temperature, resulting in negative mass balance by the end of the century.

Mass loss will increase to -0.51 m.w.e. $\mathrm{a}^{-1}$ by 2050 and -0.42 m.w.e. $\mathrm{a}^{-1}$ by the end of the century as per CNRMCM5 model projections. In case of GFDL-CM3 model projections, the loss will increase to -0.86 m.w.e. $\mathrm{a}^{-1}$ by 2050 and -1.1 m.w.e. $\mathrm{a}^{-1}$ by the end of the century. This 

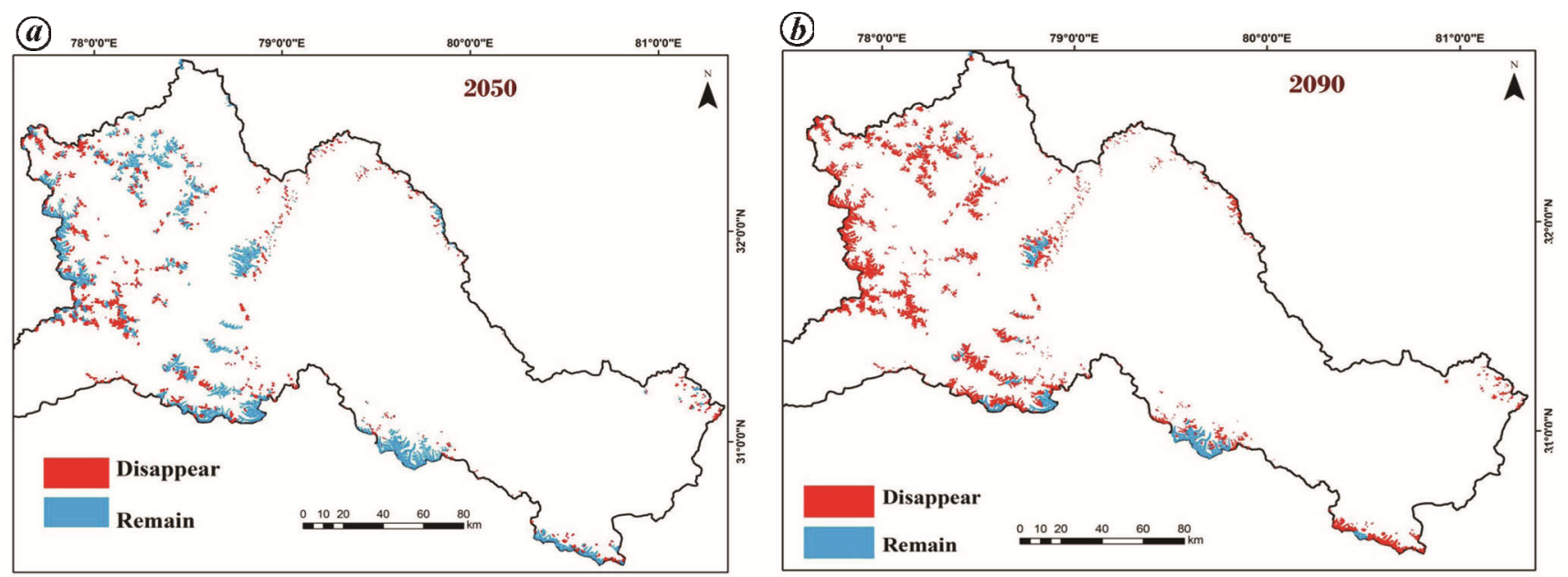

Figure 8. Projected changes in glaciers under RCP 8.5 scenario for $(\boldsymbol{a}) 2050$ and (b) 2090, based on output from the GFDL-CM3 model. By the middle of the century, $55 \%$ of the glaciers will disappear resulting in an area loss of $475 \mathrm{sq} . \mathrm{km}$. By the end of the century, $97 \%$ of the glaciers will retreat completely.

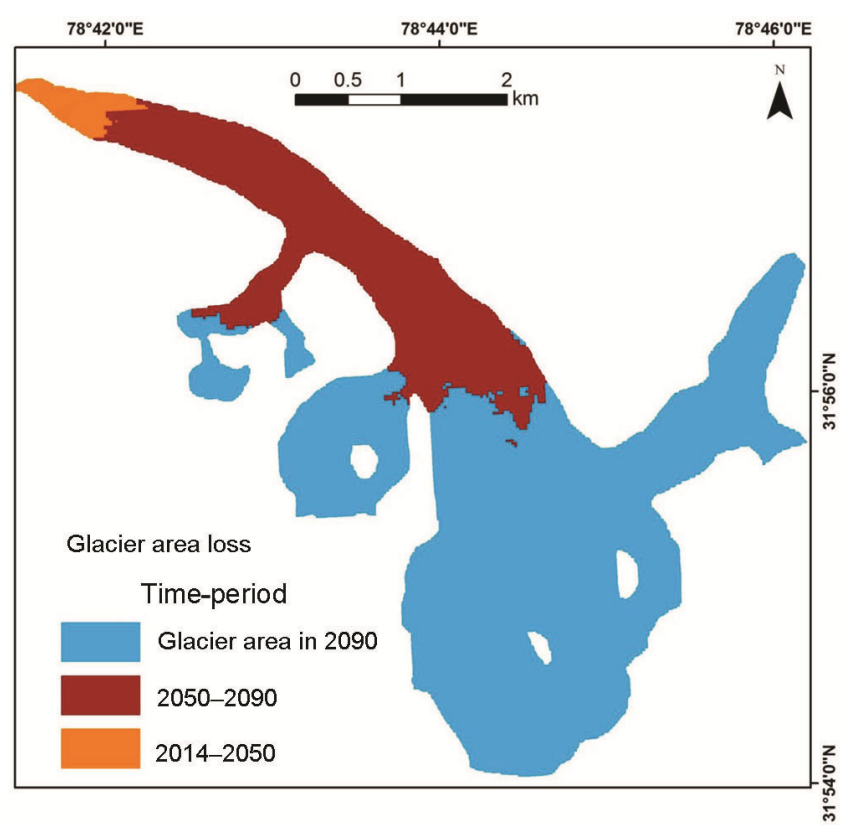

Figure 9. An example of area changes predicted under RCP 8.5 scenario from 2014 to 2090 for one of the glaciers in Spiti basin, based on GFDL-CM3 output. The glacier will lose $5 \mathrm{sq}$. km area and fragment into four parts by 2090 .

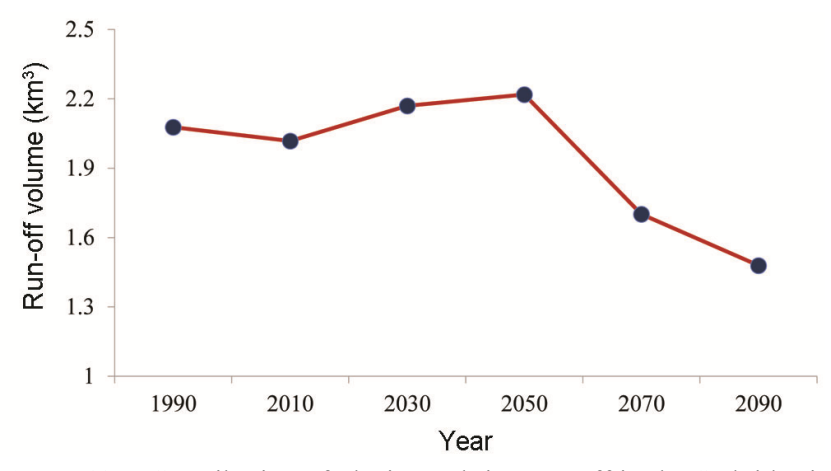

Figure 10. Contribution of glacier melt into runoff in the Satluj basin as per the GFDL-CM3 model under RCP 8.5 scenario. The melt runoff reaches its peak value by 2050 and declines thereafter. will have profound effect on the distribution of glacier extent and will result in the disappearance of $97 \%$ of the glaciers by 2090, if the region experiences extreme climate change scenario as projected by the GFDL-CM3 model.

The loss in glacier mass and area will affect the contribution of melt runoff to the Bhakra reservoir. The contribution from glacier melt will initially increase, peaking at around 2050, and will reduce thereafter. The amount of contribution will change marginally, as the glaciated area will continue to receive precipitation even under high emission scenario. However, the disappearance of smaller glaciers located at lower elevation will change the pattern 
and overall availability of water to the various hydropower projects located in the downstream areas of the basin, thereby posing new challenges for the smaller communities in the Himalayan region. Further, this will increase the occurrence of disaster events such as glacier lake outburst flood (GLOF). Thus this calls for extensive investigation and improvement in existing water management practices and new investments to improve resilience of mountain community to climate change.

1. Food and Agricultural Organization, Irrigation in Southern and Eastern Asia in figures AQUASTAT Survey-2011, 2012. FAO Water Report no. 37, 2012, pp. 129-138.

2. Immerzeel, W. W., van Beek, L. P. H., Marc, F. P. and Bierkens, M. F. P., Climate change will affect the Asian water towers. Science, 2010, 328, 1382-1385.

3. Bhakra Beas Management Board (BBMB) Report, 2016; http://bbmb.gov.in/writereaddata/Portal/Reports/15 1 BBMBANNUAL-REPORT-2015-16-E.pdf.

4. Dharmadhikary, S., Unravelling Bhakra. Econ. Polit. Wkly., 2005, 41(3), 1-10.

5. Pal, I., Lall, U., Robertson, A. W., Cane, M. A. and Bansal, R., Predictability of Western Himalayan river flow: melt seasonal inflow into Bhakra Reservoir in northern India. Hydrol. Earth Syst. Sci., 2013, 17(6), 2131-2146.

6. SANDRP, 2013; https://sandrp.files.wordpress.com/2018/03/ hep_performance_in_sutlej_river_basin_june2013.pdf (accessed on 29 May 2018).

7. Singh, D., Gupta, R. D. and Jain, S. K., Study of long-term trend in river discharge of Sutlej river (N-W Himalayan region 2014). Geogr. Environ. Sustain., 2014, 7(3), 87-96.

8. Singh, P. and Jain, S. K., Snow and glacier melt in the Satluj River at Bhakra Dam in the Western Himalayan region. Hydrol. Sci. J., 2002, 47(1), 93-106.

9. Singh, P. and Jain, S. K., Modelling of streamflow and its components for a large Himalayan basin with predominant snowmelt yield. Hydrol. Sci. J., 2003, 48(2), 257-276.

10. Oerlemans, J., Quantifying global warming from the retreat of glaciers. Science, 1994, 264(5156), 243-245.

11. Kulkarni, A. V., Rathore, B. P., Mahajan, S. and Mathur, P., Alarming retreat of Parbati glacier, Beas basin, Himachal Pradesh. Curr. Sci., 2005, 88(11), 1844-1850.

12. Chaturvedi, R. K., Kulkarni, A. V., Karyakarte, Y. and Bala, G., Glacial mass balance changes in the Karakoram and Himalaya based on CMIP5 multi-model climate projections. Climatic Change, 2014, 123(2), 315-328.

13. Tawde, S. A., Kulkarni, A. V. and Bala, G., An estimate of glacier mass balance for the Chandra basin, western Himalaya, for the period 1984-2012. Ann. Glaciol., 2017, 55(75), 99-109.

14. Dimri, A. P. and Dash, S. K., Wintertime climatic trends in the western Himalaya. Climatic Change, 2012, 111(3), 775-800.

15. Allen et al., IPCC, 2014: Annex II: Glossary (eds Mach, K. J., Planton, S. and von Stechow, C.). In Climate Change 2014: Synthesis Report, Contribution of Working Groups I, II and III to the Fifth Assessment Report of the Intergovernmental Panel on Climate Change (eds Pachauri, R. K. and Meyer, L. A.,), IPCC, Geneva, Switzerland, 2014, pp. 117-130.

16. Negi, H. S., Kanda, N., Shekha, M. S. and Ganju, A., Recent wintertime climatic variability over the North West Himalayan cryosphere. Curr. Sci., 2018, 114(4), 760-770.

17. Bolch, T. et al., The state and fate of Himalayan glaciers. Science, 2012, 336(6079), 310-314.

18. Kulkarni, A. V. and Karyakarte, Y., Observed changes in Himalaya glaciers. Curr. Sci., 2014, 106(2), 237-244.
19. Kääb, A., Chiarle, M., Raup, B. and Schneider, C., Climate change impacts on mountain glaciers and permafrost. Global Planet. Change, 2007, 56(1), 7-9.

20. Cogley, J. C., The future of Asia's glaciers. Nature, 2017, 549, $166-167$.

21. Gardelle, J., Berthier, E., Arnaud, Y. and Kaab, A., Region-wide glacier mass balances over the Pamir Karakoram-Himalaya during 1999-2011. Cryosphere, 2013, 7(6), 1885-1886.

22. Azam, M. F., Wagnon, P., Vincent, C., Ramanathan, A. L., Linda, A. and Singh, V. B., Reconstruction of the annual mass balance of Chhota Shigri Glacier (Western Himalaya, India) since 1969. Ann. Glaciol., 2014, 55, 69-80.

23. Azam, M. F., Wagnon, P., Vincent, C., Ramanathan, A. L., Favier, V., Mandal, A. and Pottakka, G., Processes governing the mass balance of Chhota Shigri Glacier (western Himalaya, India) assessed by point-scale surface energy balance measurements. Cryosphere, 2014, 8, 2195-2217.

24. Singh, M., Mishra, V. D., Thakur, N. K., Kulkarni, A. V. and Singh, M., Impact of climatic parameters on statistical stream flow sensitivity analysis for hydro power. J. Indian Soc. Remote Sens., 2009, 37(4), 601-614.

25. Kaser, G., Großhauser, M. and Marzeion, B., Contribution potential of glaciers to water availability in different climate regimes. Proc. Natl. Acad. Sci., 2010, 107(47), 20223-20227.

26. Moors, et al., Adaptation to changing water resources in the Ganges basin, northern India. Environ. Sci. Policy, 2011, 14(7), 758-769.

27. Gantayat, P., Kulkarni, A. V. and Srinivasan, J., Estimation of ice thickness using surface velocities and slope: case study at Gangotri Glacier, India. J. Glaciol., 2014, 60(220), 277-282.

28. Bahr, D. B., Meier, M. F. and Peckham, S. D., The physical basis of glacier volume-area scaling. J. Geophys. Res., 1997, 102, 20355-20362.

29. Tawde, S. A., Kulkarni, A. V. and Bala, G., Estimation of glacier mass balance on a basin scale: an approach based on satellitederived snowlines and a temperature index model. Curr. Sci., 2016, 111(12), 1977-1989.

30. Marzeion, B., Jarosch, A. H. and Hofer, M., Past and future sealevel change from the surface mass balance of glaciers. Cryosphere, 2012, 6, 1295-1322.

31. Cuffey, K. and Paterson, W. S. B., The flow of ice masses. In. The Physics of Glaciers, Elsevier, Oxford, UK, 2010, pp. 285-398.

32. Leprince, S., Barbot, S., Ayoub, F. and Avouac, J.-P., Automatic and precise orthorectification, coregistration, and subpixel correlation of satellite images, application to ground deformation measurements. IEEE Trans. Geosci. Remote Sens., 2007, 45(6), $1529-1558$.

33. Titarov, P. S., Evaluation of CARTOSAT 1 geometric potential. In The International Archives of the Photogrammetry, Remote Sensing and Spatial Information Science, Vol. XXXVII, Part B1, Beijing, 2008.

34. Nuth, C. and Kääb, A., Co-registration and bias corrections of satellite elevation data sets for quantifying glacier thickness change. Cryosphere, 2011, 5(1), 271-290.

35. Pieczonka, T., Bolch, T., Junfeng, W. and Shiyin, L., Heterogeneous mass loss of glaciers in the Aksu-Tarim Catchment (Central Tien Shan) revealed by 1976 KH-9 Hexagon and 2009 SPOT-5 stereo imagery. Remote Sens. Environ., 2013, 130, 233-244.

36. Kääb, A., Berthier, E., Nuth, C., Gardelle, J. and Arnaud, Y., Contrasting patterns of early twenty-first-century glacier mass change in the Himalayas. Nature, 2012, 488, 495-498.

37. Pratibha, S. and Kulkarni, A. V., Decadal change in supraglacial debris cover in Baspa basin, Western Himalaya. Curr. Sci., 2018, 114(4), 792-799.

38. Huss, M., Density assumptions for converting geodetic glacier volume change to mass change. Cryosphere, 2013, 7, 877887. 
39. Pieczonka, T. and Bolch, T., Region-wide glacier mass budgets and area changes for the Central Tien Shan between $\sim 1975$ and 1999 using 861 Hexagon KH-9 imagery. Global Planet. Change, 2013, 128, 862 .

40. Taylor, K. E., Stouffer, R. J. and Meehl, G. A., An overview of CMIP5 and the experiment design. Bull. Am. Meteorol. Soc., 2012, 93, 485-498; doi:10.1175/BAMS-D-11-00094.1.

41. Palazzi, E., von Hardenberg, J. and Terzago, S., Precipitation in the Karakoram-Himalaya: a CMIP5 view. Clim. Dynam., 2015, 45, 21-45.

42. Anandhi, A., Frei, A., Pierson, D. C., Schneiderman, E. M., Zion, M. S., Lounsbury, D. and Matonse, A. H., Examination of change factor methodologies for climate change impact assessment. Water Resour. Res., 2013, 47(3), 1-10.

43. Johannesson, T., Raymond, C. and Waddington, E., Time-scale for adjustment of glaciers to changes in mass balance. J. Glaciol., 1989, 35, 355-369.

44. Huss, M. and Hock, R., Global-scale hydrological response to future glacier mass loss. Nat. Clim. Change, 2018, 8(2), 135.

45. Maanya, U. S., Kulkarni, A. V., Tiwari, A., Bhar, E. D. and Srinivasan, J., Identification of potential glacial lake sites and mapping maximum extent of existing glacier lakes in Drang Drung and Samudra Tapu glaciers, Indian Himalaya. Curr. Sci., 2016, 111(3), 553-560.

46. Pfeffer, W. T. et al., The Randolph glacier inventory: a globally complete inventory of glaciers. J. Glaciol., 2014, 60(221), 537552 .
47. Taylor, J. R., An Introduction to Error Analysis: The Study of Uncertainties in Physical Measurements, University Science Books, California, USA, 1997, 2nd edn.

48. Gardner, A. S. et al., Reconciled estimate of glacier contributions to sea level rise: 2003 to 2009. Science, 2013, 340(6134), 852857.

49. Zhao, L., Ding, R. and Moore, J. C., The high Mountain Asia glacier contribution to sea-level rise from 2000 to 2050. Ann. Glaciol., 2016, 57(71), 223-231.

50. Lutz, A. F., Immerzeel, W. W., Shrestha, A. B. and Bierkens, M. F. P., Consistent increase in High Asia's runoff due to increasing glacier melt and precipitation. Nat. Clim. Change, 2014, 4, 587592 .

ACKNOWLEDGEMENTS. We thank the Department of Science and Technology, Govt. of India; Divecha Centre for Climate Change, Indian Institute of Science, Bangalore; Sustaining Himalayan Water Resources in a Changing Climate (SusHi-Wat) project, India-UK Water Centre and Impacting Research Innovation and Technology (IMPRINT) programme, Government of India for the financial support.

Received 19 December 2018; revised accepted 12 February 2019

doi: $10.18520 / \mathrm{cs} / \mathrm{v} 116 / \mathrm{i} 10 / 1721-1730$ 